\title{
The thymus medulla and its control of aßT cell development
}

\author{
Emilie J. Cosway ${ }^{1} \cdot$ Kieran D. James $^{1} \cdot$ Beth Lucas $^{1} \cdot$ Graham Anderson $^{1}$ (D) $\cdot$ Andrea J. White ${ }^{1}$
}

Received: 21 July 2020 / Accepted: 20 November 2020 / Published online: 11 December 2020

(C) The Author(s) 2020

\begin{abstract}
$\alpha \beta T$ cells are an essential component of effective immune responses. The heterogeneity that lies within them includes subsets that express diverse self-MHC-restricted $\alpha \beta T$ cell receptors, which can be further subdivided into $\mathrm{CD} 4^{+}$helper, $\mathrm{CD} 8^{+}$cytotoxic, and Foxp $3^{+}$regulatory T cells. In addition, $\alpha \beta \mathrm{T}$ cells also include invariant natural killer T cells that are very limited in $\alpha \beta \mathrm{T}$ cell receptor repertoire diversity and recognise non-polymorphic CD1d molecules that present lipid antigens. Importantly, all $\alpha \beta \mathrm{T}$ cell sublineages are dependent upon the thymus as a shared site of their development. Ongoing research has examined how the thymus balances the intrathymic production of multiple $\alpha \beta T$ cell subsets to ensure correct formation and functioning of the peripheral immune system. Experiments in both wild-type and genetically modified mice have been essential in revealing complex cellular and molecular mechanisms that regulate thymus function. In particular, studies have demonstrated the diverse and critical role that the thymus medulla plays in shaping the peripheral $\mathrm{T}$ cell pool. In this review, we summarise current knowledge on functional properties of the thymus medulla that enable the thymus to support the production of diverse $\alpha \beta$ T cell types.
\end{abstract}

Keywords Thymus $\cdot \mathrm{T}$ cell $\cdot$ Stromal cell $\cdot$ Thymocyte $\cdot$ Microenvironment

\section{Introduction}

The thymus plays an essential role in the immune system by providing a unique environment to support $\alpha \beta T$ cell development. Unlike the bone marrow, the only other primary lymphoid organ, lymphocyte development in the thymus requires the continued importation of lymphoid progenitors to ensure that $\alpha \beta$ T cells are produced throughout life. As such, the ability of the thymus to recruit, foster, and export $\alpha \beta T$ cells effectively determines how the peripheral immune system mounts effective responses. It is now clear that the multistage process of $\alpha \beta$ T cell development requires serial interactions with stromal environments that form cortical and medullary area of the thymus. While early events in thymocyte development take place in the thymic cortex and are

This article is a contribution to the special issue on: The thymus and autoimmunity - Guest Editor: Georg Holländer

Graham Anderson

g.anderson@bham.ac.uk

1 Institute of Immunology and Immunotherapy, Floor 4 Institute for Biomedical Research, Medical School, University of Birmingham, Birmingham B15 2TT, UK controlled by the cortical thymic epithelial cells (cTEC), the thymus medulla plays a pivotal role in events that ensure the correct formation of multiple $\alpha \beta$ T cell sublineages [1-3]. For example, for conventional $\alpha \beta$ T cell receptor $(\alpha \beta$ TCR) expressing thymocytes, the medulla purges the newly selected repertoire of autoreactive specificities via negative selection, and supports their post-selection thymocyte maturation and egress from the thymus [4]. In addition, through interactions with medullary thymic epithelial cells (mTEC) and dendritic cells (DC), the thymus medulla enables lineage diversion of $\mathrm{CD}^{+}$single-positive (CD4SP) thymocytes to $\mathrm{Foxp}^{+} \mathrm{T}$ regulatory (T-Reg) cells that control anti-self-immune responses [5]. Finally, the thymus medulla provides multiple signals that enable CD1d-restricted invariant natural killer T (iNKT) cells to complete their intrathymic maturation [6]. Thus, the thymus medulla generates multiple $\alpha \beta$ T cell types that play important roles in both innate and adaptive immunity. Indeed, the functional importance of the thymus medulla is readily evident in the disruption of immune homeostasis and manifestation of autoimmunity that occurs when its development and/or function is impaired. This can include the consequences of naturally occurring or experimentally induced genetic mutations that take place either in the cells that help form the medulla (e.g. Aire, Relb in mTEC) or in the cells that the medulla fosters (e.g. Foxp3 in T-Reg) [7-10]. Given this importance 
and the recent advances made in understanding the cellular complexity of mTEC, the primary focus of this review is to examine the cell types that reside within the thymus medulla, and examine how they form microenvironments that shape key events during intrathymic $\alpha \beta$ T cell development.

\section{mTEC functionality and function}

\section{MHCII $^{\text {hi }}$ CD80 ${ }^{\text {hi }}$ mTEC $^{\text {hi }}$}

mTEC are classically defined as an Ly51 UEA- $1^{+}$subset of total $\mathrm{EpCAM}^{+} \mathrm{TEC}$. Within the bulk mTEC population, analysis of MHCII and CD80 reveals mTEC $^{\mathrm{lo}}\left(\mathrm{MHCII}^{\mathrm{lo}} \mathrm{CD} 80^{\mathrm{lo}}\right.$ ) and mTEC $^{\text {hi }}\left(\mathrm{MHCII}^{\mathrm{hi}} \mathrm{CD} 80^{\mathrm{hi}}\right)$ subsets. While much effort has been made to understand the developmental relationships of mTEC subsets, mTEC pathways are still not fully understood. For example, while $\mathrm{mTEC}^{\mathrm{lo}}$ are known to contain progenitors of $\mathrm{MTEC}^{\text {hi }}$, they also contain cells that are 'ex-mTEC hi' and so represent late stages of mTEC development.

An important role of mTEC $^{\text {hi }}$ is the induction of central tolerance, which involves the screening of $\alpha \beta T C R$ specificities that newly positively selected single positive (SP) thymocytes express. This becomes possible as a proportion of mTEC $^{\text {hi }}$ express autoimmune regulator (Aire), with the development of Aire ${ }^{+}$being driven by cell surface receptors that are members of the tumour necrosis factor superfamily, notably RANK [11-14]. Aire expression by TTEC $^{\text {hi }}$ allows for the presentation of tissue-restricted antigens (TRAs) by via MHCI and MHCII, enabling the effective screening of developing thymocytes for their TCR specificity against self [11]. The molecular mechanisms that control Aire-mediated expression are beginning to emerge $[15,16]$. Some studies propose that Aire functions through its recruitment to target genes where it causes localised histone modifications via either histone methylation or acetylation which relaxes chromatin for subsequent TRA transcription [17]. In addition, the protein deacetylase Sirtuin-1 or Sirt1 was shown to be highly expressed in mature Aire-expressing mTEC and it remains closely associated with Aire itself, resulting in the deacetylation of Aire that is necessary for its transcriptional activity [18]. In addition to Aire, some mTEC $^{\text {hi }}$ express the transcription factor FEZ family zinc finger 2 (Fezf2), which has been reported to allow for expression of TRAs by mTEC that are distinct from those under the control of Aire [19]. However unlike Aire, Fezf2 is not restricted solely to mTEC $^{\text {hi }}$, with Fezf2 ${ }^{+}$cells also present within the mTEC ${ }^{\text {lo }}$ compartment. Indeed, and in contrast to earlier observations, both Aire and Fezf2 are controlled by RANK signalling, with LT $\beta R$ dispensable for Fezf2 expression [20]. Significantly, deletion of Fezf2 in TEC did not impair Aire expression, but resulted in an autoimmune phenotype, suggesting the functional importance of Fezf2 expression in the thymus for immune tolerance [19]. Therefore Aire and Fezf2 may function cooperatively, allowing for a more extensive TRA expression profile [21].

\section{$\mathrm{MHCII}^{\mathrm{lo}} \mathrm{CD}^{\mathrm{lo}} \mathrm{mTEC}^{\mathrm{lo}}$}

The TTEC $^{\text {lo }}$ subset was originally described as an immature progenitor population that gave rise to $\mathrm{mTEC}^{\text {hi }}$ following RANK and CD40 stimulation. However, it has also been shown that TTEC $^{\text {hi }}$ could revert back to a TTEC $^{\text {lo }}$ phenotype following Aire expression [12, 22], suggesting that there is considerable heterogeneity within mTEC $^{\mathrm{lo}}$. This fits well with recent studies uncovering multiple and distinct mTEC subsets using single-cell RNA-Seq analysis [23-26], and further work is necessary to understand the development relationships and functionality of these subsets.

mTEC $^{\text {lo }}$ that are generated from mTEC $^{\text {hi }}$ are composed of multiple subsets. For example, they can begin to express markers including involucrin that are representative of terminally differentiated epithelial cells such as keratinocytes, which may further lead to the formation of structures that resemble Hassall's corpuscles [27, 28]. These are readily identifiable in the human thymus, where they have been linked to DC activation and T-Reg generation [29]. In mice, though less pronounced in size and frequency, such structures have also been reported to play a role in DC activation that drives IFN- $\alpha$ production and T cell maturation [30]. An additional subset of $\mathrm{mTEC}^{\mathrm{lo}}$, some of which are generated post Aire expression, are thymic tuft cells $[23,24]$, which are also seen in the human thymus $[23,27,31,32]$. In mice (designated $L T \beta R^{\mathrm{TEC}}$ ), deletion of LT $\beta$ R in TEC resulted in an absence of thymic tuft cells [33], which fits well with the importance of LT $\beta R$ signalling during mTEC terminal maturation $[34,35]$. Interestingly, analysis of tuft cells from different anatomical sites such as the colon, trachea, thymus, and bladder highlighted tissue-specific features of tuft cells and also showed that gut and thymus tuft cells had many similarities, including expression of IL-25, Dclk1, Trmp5, and Pou2f3 [36]. While the functional properties of thymic tuft cells have not yet been fully examined, conventional thymocyte development appears grossly normal in the absence of tuft cells [23, 24]. However, there is some evidence suggesting that through their expression of cell-type-specific molecules, tuft cells play a role in T cell tolerance mechanisms [24]. In addition, subtle defects in T-Reg [37], ILC2 [23], and iNKT cells [24, 33] have also been reported in tuft cell-deficient mice. Indeed, IL-25 expression by tuft cells was recently shown to influence IL-4-producing iNKT cells that regulate thymic DC [33]. Thus, emerging evidence suggests that tuft cells represent a functionally relevant $\mathrm{mTEC}$ subset in the thymus, which fits well with the idea that subsets within $\mathrm{mTEC}^{\mathrm{lo}}$ are linked to thymus function.

Another striking example of the ability of $\mathrm{mTEC}^{\text {lo }}$ to influence $\mathrm{T}$ cell development is the identification of a subset that expresses the chemokine CCL21 [38]. Indeed, an essential 
requirement for CCL21 in the control of cortex to medulla migration of positively selected thymocytes identifies $\mathrm{CCL} \mathrm{1}^{+} \mathrm{mTEC}^{\mathrm{lo}}$ as a critical, functionally mature $\mathrm{mTEC}^{\mathrm{lo}}$ subset [39]. Interestingly, while the frequency of CCL2 $1^{+}$ mTEC $^{\text {lo }}$ is reduced in LT $\beta R$-deficient mice [38], their levels of CCL21 expression are not altered [33]. Thus, LT $\beta R$ may control proliferation and/or survival of CCL2 $1^{+}$mTEC $^{\text {lo }}$. However, the precursor-product relationships that give rise to $\mathrm{CCL} 21^{+} \mathrm{mTEC}^{\text {lo }}$ in relation to other $\mathrm{mTEC}^{\text {lo }}$ subsets, including tuft cells, are not well understood. The generation of CCL21-reporter mice [39] and the recent identification of CD104 as a cell surface marker of CCL2 $1^{+}$-producing cells within mTEC $^{\text {lo }}$ [33] should enable the direct isolation and further characterisation of these cells.

\section{Thymic dendritic cells and central tolerance}

As well as the documented function of mTEC, DC can also be found in the thymus medulla from the late stages of embryogenesis, where they aid central tolerance induction $[33,40]$. There are three populations of DC within the thymus, two conventional $\mathrm{DC}$ subsets ( $\mathrm{cDC} 1$ and $\mathrm{cDC} 2)$ and plasmacytoid DC (pDC) [41, 42].

\section{Intrathymic conventional dendritic cells 1}

Recent findings indicate that conventional dendritic cells 1 (cDC1) develop from migrant pre-cDC progenitors that are distinct from the lymphoid lineage, and are recruited to the thymus via CCR7-CCL21 [43, 44]. Intrathymic cDC1 are typically localised within the medulla as they express the chemokine receptor XCR1 and mTEC produce its ligand XCL1 in an Airedependent manner [45]. The localisation of $\mathrm{CDC1}$ near to $\mathrm{mTEC}$ is likely paramount to their function, as they specifically assist central tolerance by cross-presenting antigen via apoptotic material release or trogocytosis from Aire $^{+}$mTEC [46-48]. In a recent study, depletion of both $\mathrm{CDC} 1$ and $\mathrm{mTEC}$ resulted in the induction of organ-specific autoimmunity that was not seen in the selective absence of either $\mathrm{mTEC}$ or $\mathrm{CDC} 1$ alone, suggesting a cooperative functioning between these two populations for central tolerance [49]. Similarly, aly/aly mice with a point mutation in the NF- $\mathrm{KB}$-inducing kinase (NIK) gene show disrupted mTEC and $\mathrm{cDC} 1$ numbers with subsequent peripheral autoimmunity, thus reinforcing the requirement for cross-talk between $\mathrm{cDC1}$ and $\mathrm{mTEC}$ for negative selection [50].

\section{Thymic recruitment and function of extrathymic DC}

$\mathrm{cDC} 2$ and $\mathrm{pDC}$ migrate into the thymus as mature cells and utilise cell adhesion molecules to gain thymic entry $[51,52]$. cDC2 are recruited to the thymus through CCR2 expression with CCL8 (MCP-2) expressed by cTEC and surrounding blood vessels [53]. pDC migrate to the thymus via CCR9 expression and are likely attracted by CCL25-expressing TEC [52]. Additionally, pDC recruitment to the thymus may involve additional chemokine receptors and ligands. For example, pDC are receptive to CCR7 ligands in transwell migration assays [54]. Following thymic entry, $\mathrm{cDC} 2$ and pDC undergo extensive proliferation and upregulate expression of MHCII and CD80/CD86 priming them to interact with developing thymocytes and support tolerance induction [41]. Their ability to induce negative selection was demonstrated when OVA-pulsed DC were transferred intravenously into OT-II TCR transgenic mice, which resulted in the induction of thymocyte negative selection $[41,51]$. In addition, as $\mathrm{CDC} 2$ are situated around blood vessels in the thymus, they are well placed to capture and present circulating antigens to support negative selection $[53,55,56]$. Furthermore, the capacity of the thymus to induce negative selection was shown to be increased by 4 weeks of age, and this correlated with a greater number of $\mathrm{cDC} 2$ migrating to the thymus with enhanced ability to present and process self-antigen [57].

\section{Thymic DC and T regulatory cell development}

In addition to negative selection, DC have been associated with a role for induction of T-Reg development in the thymus [58]. This idea was originally controversial, as ablation of DC did not influence thymic T-Reg numbers [59, 60]. However, other studies have suggested that DC and mTEC play nonoverlapping roles in the production of T-Reg with distinct TCR repertoires and that Batf3-dependent DC $(\mathrm{cDC} 1)$ are crucial for T-Reg selection through acquisition and presentation of Aire-dependent antigens [61]. Interestingly, while these studies indicate the ability of DC to influence T-Reg development, they also suggest that some thymic DC may be more effective at supporting T-Reg generation than others. Whether this is due to differences in the intrathymic positioning of different DC subsets, or differences in their functional abilities as antigen-presenting cells, is not clear. Relevant to this, it is interesting to note that thymic DC have been reported as a source of IL-2 which is required for intrathymic T-Reg development [62] suggesting that the involvement of these cells in T-Reg generation extends beyond their provision of TCR ligands. Interestingly, however, IL-2 has also been shown to be produced by self-reactive CD4SP thymocytes [63], indicating that multiple cellular sources of IL-2 can influence T-Reg development in the thymus.

\section{Post-selection maturation of conventional aßT cells}

In addition to mediating tolerance induction, the medulla also provides signals to ensure that conventional (i.e. 
CD25 ${ }^{-}$Foxp $3^{-}$CD1dtetramer ${ }^{-}$) CD4SP and CD8SP thymocytes undergo a differentiation programme prior to their exit from the thymus and entry into the circulation as recent thymic emigrants (RTE). As such, medullary located conventional SP thymocytes progress through a series of maturational stages that can be identified by expression of phenotypic markers, and acquisition of functional properties.

\section{Defining maturational states in conventional SP thymocytes}

Classically, CD4 and CD8 are used to identify and study specific stages in $\mathrm{T}$ cell development in the thymus. For example, immature $\mathrm{T}$ cell progenitors reside within the $\mathrm{CD} 4^{-} \mathrm{CD} 8^{-}$ compartment which give rise to $\mathrm{CD} 4^{+} \mathrm{CD} 8^{+}$cortical thymocytes. These then undergo selection events to generate CD4SP and CD8SP cells. Following identification of 4 main thymocyte populations based on CD4 and CD8 expression, later studies identified further heterogeneity within SP thymocytes. As discussed previously, this suggested different maturational states of SP thymocytes in the thymus [64]. Indeed, experiments involving BrdU pulse chase analysis provided strong evidence for distinct stages in the post-selection maturation of SP thymocytes [65]. Currently, many different parameters are also used to subdivide conventional SP thymocytes, in the hope of reaching a consensus on the maturational sequence of $\mathrm{T}$ cell development in the medulla [50, 66-69]. The use of Rag2GFP reporter mice has significantly helped in the accurate study of SP thymocyte maturation. For example, by separating bulk CD4SP thymocytes into 3 groups identified by differing Rag2GFP levels, initial studies showed that the most immature cells expressed high levels of CD69 and CD24. As these cells mature further, they downregulate CD69 and CD24 and upregulate CD62L and Qa2 [70, 71]. Thus, immature $\mathrm{CD} 4 \mathrm{SP}$ thymocytes are $\mathrm{CD} 24^{+} \mathrm{CD} 69^{+} \mathrm{CD} 2 \mathrm{~L}^{-}$, while mature cells are $\mathrm{CD} 24^{-} \mathrm{CD} 69^{-} \mathrm{CD} 62 \mathrm{~L}^{+}$, and this transition is being accompanied by progressive loss of Rag2GFP levels. Additional cell surface markers including $6 \mathrm{C} 10$ and the chemokine receptors CCR7 and CCR9 also help define SP thymocytes and their precursor-product relationships [66, 68]. For example, using 6C10, CD69, and Qa2 expression, studies have shown that intrathymic transfer of immature $\mathrm{CD} 9^{+} 6 \mathrm{C} 10^{+} \mathrm{Qa} 2^{-}$(SP1) cells generated downstream $\mathrm{CD}^{\circ} 9^{+} 6 \mathrm{C} 10^{-} \mathrm{Qa}^{-}$(SP2), $\mathrm{CD}^{-} 9^{-} 6 \mathrm{C} 10^{-} \mathrm{Qa}^{-}$(SP3), and $\mathrm{CD}^{-} 9^{-} 6 \mathrm{C} 10^{-} \mathrm{Qa}^{+}(\mathrm{SP} 4)$ populations $[72,73]$. A summary of the various ways SP thymocytes have been subdivided is shown in Fig. 1.

While current studies frequently utilise combinations of the above markers in analysis of SP thymocytes, important observations have been made regarding the use of Qa2 [74]. Here, Qa2 levels in SP thymocytes were shown to be influenced by type I interferon signalling and so may not accurately reflect the maturational status of cell subsets [74]. Subsequently, an alternative method was described using CD69 and MHC I to identify 3 populations of SP thymocytes: SM $\left(\mathrm{CD} 69^{+} \mathrm{MHC}\right.$ $\left.\mathrm{I}^{-}\right), \mathrm{M} 1\left(\mathrm{CD}^{-} 9^{+} \mathrm{MHC} \mathrm{I}^{+}\right)$, and M2 (CD69- $\left.\mathrm{MHC} \mathrm{I}^{+}\right)$[74]. The maturational relationship between these three populations was confirmed by Rag2GFP levels, as well as by identifying SM, $\mathrm{M} 1$, and M2 populations within previously established strategies, such as the SP1-4 or CCR7/CCR9 staining combinations [74]. Furthermore, the strength of this approach can be seen in the stratification of cell function to each subset. First, the switch to proliferation competence following TCR signalling was shown to occur at the M1 stage of development [74]. Second, maturation to M2 defines when thymocytes become 'cytokine licenced' and produce IFN $\gamma$ and TNF- $\alpha$ upon TCR stimulation. Finally, the M2 stage marks the ability of SP thymocytes to exit the thymus [74]. The ability to accurately define progressive functional changes in SP thymocytes and the processes that control this rely on the ability to phenotypically define distinct developmental stages. As such, reaching a consensus on the panel of markers by researchers in the field, perhaps CD69/MHCI/CD62L/CCR7/CCR9 may aid progress in this area. It is also worth noting that much of the work described above relates primarily to CD4SP thymocytes, and while some marker combinations can help in subdividing CD8SP, there are clear differences in marker expression within the two lineages, suggesting that lineage-specific maturation markers may be required to accurately draw up a roadmap of both CD4SP and CD8SP thymocyte heterogeneity.

\section{Regulation of post-selection maturation}

Consistent with its importance in $\mathrm{T}$ cell tolerance, mice that lack mTEC (e.g. Relb ${ }^{-1}$ mice) or lack controllers of medullary access (e.g. $\mathrm{Ccr} T^{-/}$mice and pltpplt mice) develop autoimmunity $[75,76]$. However, it is not clear to what extent mTEC may provide important signals that guide postselection maturation. Indeed, the presence of phenotypically mature SP thymocytes in the thymus of $\mathrm{Relb}^{-/}$and $\mathrm{Crr}^{-/}$ mice, and the presence of $\mathrm{T}$ cells in peripheral tissues, argues against an essential requirement for mTEC in post-selection maturation and thymic exit $[39,68,77,78]$. However, it should be noted that mice with medullary defects have been reported to have defects in SP thymocytes, including a developmental block in CD4SP post-selection maturation in both $\mathrm{Relb}^{-/-}$and Aire ${ }^{-/-}$strains [72]. However, as these observations used Qa2 expression to measure maturation status, it is not clear whether there is indeed a maturation defect in these mice or whether altered Qa2 expression levels are a result of disruption of type I interferon signalling as discussed above [74]. Indeed, when $\mathrm{Relb}^{-/}$thymus lobes were grafted under the kidney capsule of wild-type (WT) hosts, CD4SP thymocyte maturation appeared normal, indicating that phenotypic CD4SP thymocyte maturation can occur independently of mTEC [68]. 


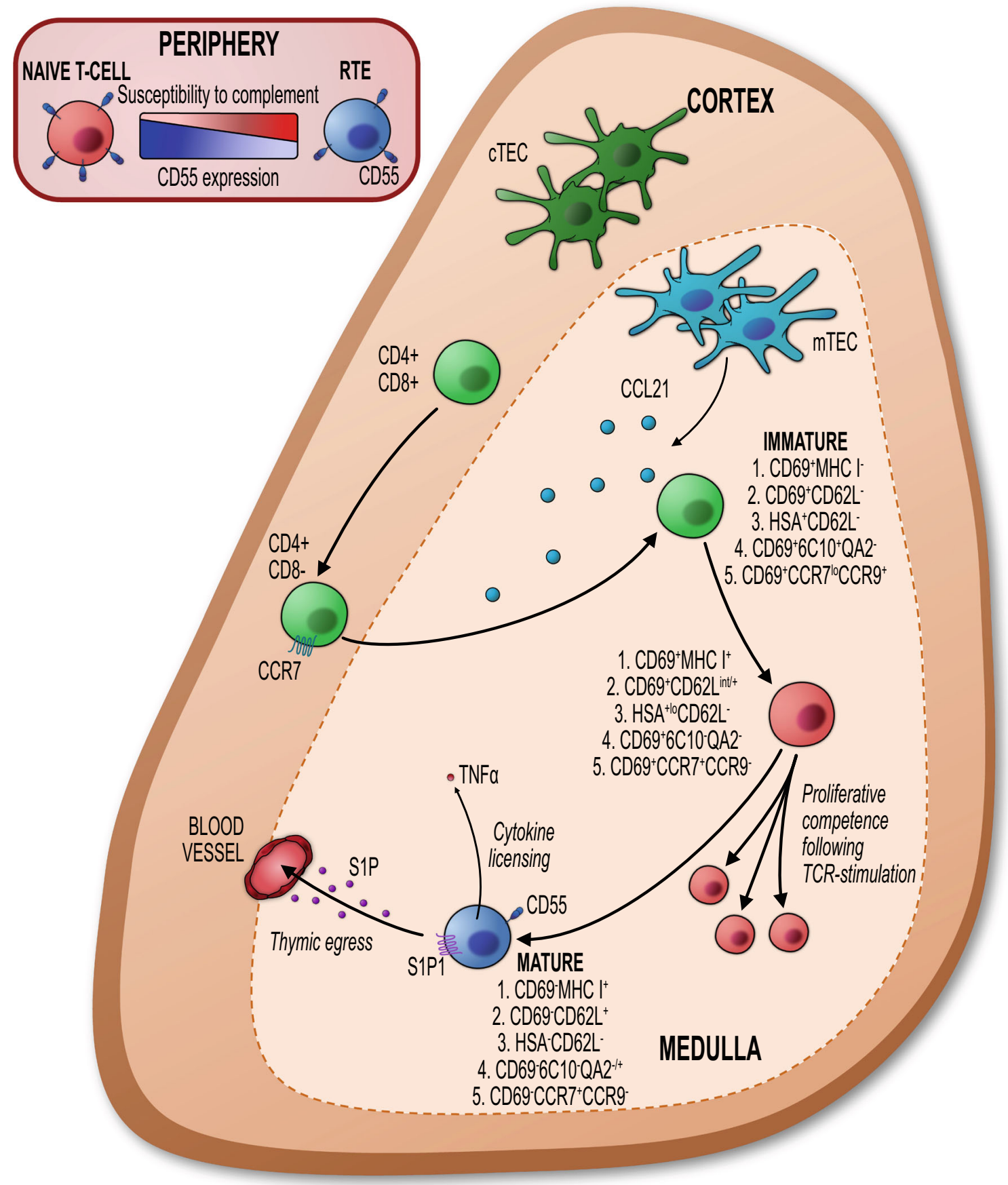

Fig. 1 Phenotypic approaches to characterise post-selection maturation of conventional CD4SP $\alpha \beta$ T cells. CD4SP conventional thymocytes mature within the medulla, undergoing a number of phenotypic and functional changes. A consensus on which combination of phenotypic markers to use to identify each maturation state has not been reached, and different gating strategies have been used within the literature. Markers used, and how the expression of each changes through maturation, can be followed using the 1-5 numbering system for each of the different strategies that have been proposed. For example, \#1 indicates the expression of CD69 and MHCI at each stage; immature $\mathrm{CD}^{+} 9^{+} \mathrm{MHCI} \rightarrow \mathrm{CD}^{-} 9^{+} \mathrm{MHCI}^{+} \rightarrow$ mature $\mathrm{CD}^{-} 9^{-} \mathrm{MHCI}^{+}$. Following

Interestingly, other studies provide evidence that the thymus medulla and/or mTEC may subtly influence the initial maturation from an 'immature' state, CD4SP thymocytes gain the ability to proliferate in response to TCR ligation. Subsequent intrathymic maturation marks a transition when CD4SP thymocytes gain a series of functions: they upregulate CD55 to aid their protection from complement [83], become 'cytokine licenced' wherein they produce cytokines upon stimulation [74] and then expression of S1P1, which is essential for thymic egress, and entry into the periphery as recent thymic emigrants (RTE) $[74,81]$. Although expression of CD55 is initiated in the thymus, its expression continues to increase in the periphery, reaching maximum levels on naïve $\alpha \beta$ T cells [83]

functional qualities of mature SP thymocytes and RTE. For example, when SP thymocytes of differing maturation states 
were isolated, intrathymically injected, and analysed 1 or 4 days post-injection, Jin et al. showed that cells spending longer in the thymus contained an increased proportion of IL-2, IL-4, and IL-10, as well as IFN $\gamma$-producing cells [73]. Thus, intrathymic dwell time may be proportional to functional acquisition, suggesting that the longer the time that thymocytes are able to spend within the thymus, the greater their functional capabilities. While the signalling events and mediators that control post-selection maturation are not well understood, examination of SM/M1/M2 SP thymocyte populations demonstrated that NF-KB- and IRF-regulated gene changes occurred later after positive selection [74]. Moreover, following deletion of Takl (an important kinase in the NF- $\mathrm{kB}$ pathway), a block in the maturation at the SM stage was observed [74], with Takl also protecting cells from TNF-induced death [74]. Similarly, a study investigating the role of NF-KB signalling in thymocyte development showed that deletion of the two subunits of the inhibitor of $\mathrm{kB}$ kinase (IKK) complex (IKK1 and IKK2) in thymocytes resulted in complete arrest of SP maturation at the immature CD24 ${ }^{\text {hi }}$ stage [79]. Moreover, TNF signalling via TNFR1 was found to be required for activation of the NF- $\mathrm{KB}$ pathway, which was essential in protecting cells from TNF-mediated cell death [79]. Additional work from the same group confirmed this role for IKK in thymocyte survival and proliferation, but clarified that the essential role of the IKK activity is to repress RIPK1kinase-dependent cell death by a mechanism which is independent of NF-kB [80]. Importantly, while some of the intracellular signalling cascades that are active in thymocytes to control post-selection maturation have been identified, the cell-cell interactions that trigger these signalling events are unclear.

\section{Thymus egress and SP thymocytes}

The ability of SP thymocytes to exit the thymus is essential to establish the peripheral $\mathrm{T}$ cell pool. Egress competence is restricted to the mature fraction of thymocytes that express the sphingosine-1-phosphate (S1P) receptor 1 (S1PR1), which is essential for egress [81]. In relation to the control of this process, it has been reported that ligation of CCR2 on SP thymocytes induces activation of the transcription factor FOXO1KLF2 axis which ultimately leads to expression of S1PR1, as well as enhancing S1P-induced chemotaxis itself [71, 73, 81, 82]. The importance of egress competency being limited to the most mature SP fraction may be beneficial as it may mean that only SP thymocytes that have undergone a full intrathymic maturation programme have the ability to leave the thymus, which may regulates the quality of the peripheral $\mathrm{T}$ cell pool. Relevant to this are studies examining patterns of expression of the cell surface marker CD55 in thymocyte subsets. For example, as CD55 protects peripheral $\mathrm{T}$ cells from complement-mediated cell death and high CD55 levels are limited to the most mature SP thymocytes [83], this indicates cells that have undergone full intrathymic maturation may have an enhanced ability to survive in the periphery [83]. Whether or not medullary residency, and contact with $\mathrm{mTEC}$, is required for this process is not clear.

While the importance of S1PR1 expression by SP thymocytes in thymus emigration is well described, several differing models of emigration have been proposed. This is perhaps best represented by 'conveyor belt' and 'lucky dip' models of thymic exit [84]. In the former, exit of egress-competent thymocytes occurs in a developmentally controlled manner, suggesting that all SP thymocytes spend a similar period of time in the thymus. By contrast, the lucky dip model suggests that once SP thymocytes reach egress competence, they are eligible to leave the thymus irrespective of the amount of time they have spent in the medulla, and a consequence of this would be the export of cells of different ages. Recently, we used CD62L levels to identify subpopulations of

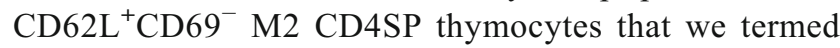
M2a, M2b, and M2c on the basis of their Rag2GFP levels, with M2a showing the highest GFP levels (as so are least mature) and M2c showing the lowest GFP levels (and so are the most mature). Using this approach, we showed that thymus egress follows an ordered regimen that supports a conveyor belt process rather than a random lucky dip. Thus, M2c thymocytes expressed the highest levels of S1PR1, perhaps giving the most mature cells a greater ability to exit the thymus, while cells within thymic perivascular spaces that represent sites of exit were enriched in M2c cells [85]. Therefore, while M2 (mature) thymocytes have the capacity to exit the thymus, within that population, there are cells with a greater ability to leave that is based on their age. What controls this ordered process of emigration is not known. However, it is interesting that while LT $\beta \mathrm{R}$ is an important regulator of thymic exit $[67,85]$, thymic emigration in LT $\beta$ R-deficient mice still follows a conveyor belt mechanism [67, 85]. Further work is required to identify the microenvironmental signals that ensure thymus emigration is biased towards the most mature SP thymocytes.

As the cortico-medullary junction is a region containing blood vessels that represent sites of thymic exit, it is likely that TEC, and mTEC in particular, influence thymic egress. Indeed, in neonatal $\mathrm{Crr}^{-1}$ mice where thymocyte migration to mTEC-derived chemokines CCL19 and CCL21 is abolished, thymus emigration is defective and results in intrathymic SP accumulation and a reduction in peripheral $\mathrm{T}$ cell numbers $[78,86]$. That thymus emigration is not impaired in adult $\mathrm{Ccr}^{-/}$mice [77, 86] indicates an interesting distinction to the neonate and suggests that the regulators of thymic exit, perhaps including a requirement mTEC themselves, are different at distinct stages of the life course. Additionally, in adult mice, mTEC can influence thymic egress by maintaining the S1P gradient essential for egress via their expression of 
lipid phosphate phosphatase (LPP3), an enzyme which dephosphorylates S1P to maintain S1P gradients [87]. In this study, deletion of LPP3 in $\mathrm{K} 14^{\mathrm{Cre}}$-positive TEC resulted in the intrathymic accumulation of mature SP thymocytes. It has also been shown that mTEC influence mature thymocyte egress indirectly, by regulating other lymphocyte populations that are present within the medulla. For example, LT $\beta$ Rdependent regulation of iNKT cells regulates thymic egress $[88,89]$, while the influence of mTEC on DC via-NIK (NF-KB-inducing kinase) signalling is also required for normal thymocyte egress [50]. Again, much of the work carried out on thymus egress relates to CD4SP thymocytes and adult thymus. Given the different maturational pathways for CD4SP and CD8SP, and the differential requirement for CCR7 in neonatal but not adult thymus egress, further work is required to fully understand the role of the thymus medulla in controlling this process.

\section{iNKT cell development in the thymus medulla}

\section{Redefining pathways in iNKT cell development}

As is the case for conventional CD4SP and CD8SP thymocytes, iNKT cells arise from $\mathrm{CD} 4^{+} \mathrm{CD} 8^{+}$thymocytes that reside in the cortex [90]. However, unlike these other lineages, iNKT cells do not recognise self-peptide/MHC complexes expressed by cTEC. Instead, interactions between $\mathrm{CD} 4^{+} \mathrm{CD} 8^{+}$thymocytes involving an invariant $\alpha \beta \mathrm{TCR}$ and lipid-presenting CD1d molecules initiate iNKT cell development [91]. Importantly, iNKT cells are an effective component of immune responses where they connect innate and adaptive arms of the immune system through their rapid production of cytokines that include IL-4, IFN $\gamma$, and IL-17 [6]. In early studies, cell surface markers such as CD24, NK1.1, and CD44 were used to suggest a linear sequence of iNKT cell development $[92,93]$. More recently, use of $\mathrm{CD} 1 \mathrm{~d} / \alpha-$ galactosylceramide $(\mathrm{CD} 1 \mathrm{~d} / \alpha \mathrm{GC})$ tetramer reagents alongside transcription factor and cytokine expression revealed the development of multiple iNKT sublineages within the thymus. Similar to $\mathrm{T}$ helper cell nomenclature, three iNKT sublineages have been described: iNKT1 are T-bet ${ }^{+}$and produce IFN $\gamma$, and NNKT$_{2}$ are PLZF $^{+}$and produce IL-4, while iNKT17 are ROR $\gamma \mathrm{t}^{+}$and produce IL-17 [94]. Although largely in agreement with the original description of these subsets, a subsequent study has also shown co-production of cytokines by iNKT cells following stimulation, in particular IL-4/IFN $\gamma$ and IL-4/IL-17 by iNKT2 [95]. Interestingly, the composition of iNKT cells in the thymus of inbred strains of WT mice also differs. For example, C57Bl/6 mice have a prominent population of iNKT1, whereas iNKT in BALB/c mice are heavily dominated by iNKT2. Given that iNKT1 are defined by IFN $\gamma$ expression while iNKT2 are defined by IL-4, this fits well with the respective type $1 /$ type 2 immunity in these strains.

The identification of multiple iNKT sublineages in the thymus raises questions about the developmental pathways that give rise to these cells. Importantly, Lee et al. identified CCR7 expression as a potential iNKT cell progenitor marker [96]. Analysis of iNKT cell development in Rag2GFP mice showed that in contrast to $\mathrm{CCR}^{-}{ }^{-}$iNKT cells, $\mathrm{CCR}^{+}{ }^{+}{ }_{\mathrm{iNKT}}$ cells retain some GFP expression, indicative of an early stage in iNKT cell development [97]. Importantly, CCR $7^{+} \mathrm{Rag} 2 \mathrm{GFP}^{+}$ iNKT cells gave rise to iNKT1, iNKT2, and iNKT17 cells following their intrathymic transfer, providing direct evidence they represent a common iNKT progenitor. Interestingly, $\mathrm{CCR} 7^{+} \mathrm{Rag} 2 \mathrm{GFP}^{+}$iNKT progenitors express markers previously shown to be present early in iNKT cell development such as Plzf and Lef1 [97]. However, they lack expression of transcription factors and cytokines that indicate more mature iNKT cells such as ROR $\gamma$, T-bet, and IL-4 [97]. Interestingly, $\mathrm{CCR} 7^{+}$iNKT cell progenitors can also exit the thymus and continue their development towards iNKT1, iNKT2, and iNKT17 extrathymically [97]. Why some CCR $7^{+}$iNKT progenitors choose to complete their maturation intrathymically as opposed to maturing extrathymically is not clear.

\section{Intrathymic control of iNKT lineage heterogeneity}

Although initial stages of iNKT cell development require interactions between DP thymocytes in the cortex, analysis of $\mathrm{Relb}^{-1-}$ mice demonstrates a clear requirement for mTEC in their downstream maturation [34] (Fig. 2). Consistent with this, iNKT cells are primarily located within the thymus medulla in the adult mouse [98]. This positioning is partially dependent on CCR7, as mixed chimeras using WT and $\mathrm{CCr}^{-/}$bone marrow resulted in the mispositioning of some $C \mathrm{cr}^{-1}$ iNKT cells to the thymic cortex [97]. Studies that have highlighted the significance of the thymus medulla for iNKT cells have raised important questions about factors produced by mTEC, and whether particular mTEC subsets influence the development of individual iNKT subsets.

The identification of multiple intrathymic iNKT subsets, together with an expansion of our understanding of mTEC heterogeneity, has allowed further examination of links between mTEC and iNKT cells. In a recent study, $L T \beta R^{T E C}$ mice, which specifically lack expression of LT $\beta$ R by TEC, have been used to determine the effects of disrupted medullary environments on iNKT cell development [33]. This study showed that LT $\beta R$ controls the frequency of CD $104^{+} \mathrm{CCL}_{2} 1^{+}$mTEC $^{\text {lo }}[33,38]$ that are capable of IL-15 transpresentation, which has been linked to the proliferation and survival of iNKT cells $[34,99]$. Interestingly, CD122 (a subunit of IL-15 receptor) is expressed by all thymic iNKT cells with the highest levels being expressed by iNKT1 $[33$, 


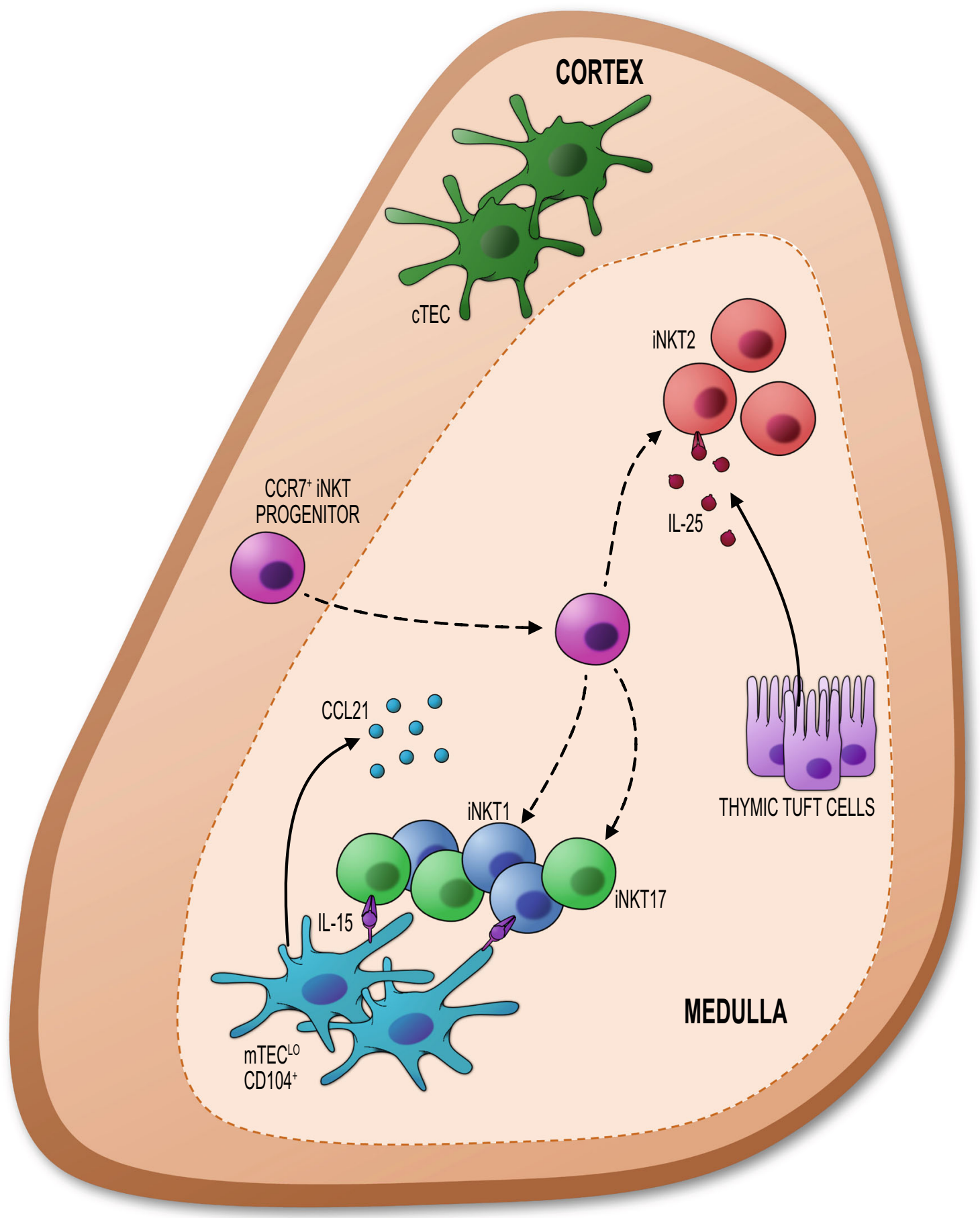

Fig. 2 Regulation of intrathymic iNKT cell development by distinct populations of mTEC. CCR $7^{+}$iNKT cell progenitors migrate into the thymus medulla in a CCR7-dependant manner. Here, perhaps under the influence of medullary stroma, they can undergo further differentiation to generate iNKT1, iNKT2, and iNKT17 subsets. The IL15R $\alpha$-mediated

94], and in vivo administration of IL-15/IL-15R $\alpha$ complexes increased iNKT1 and iNKT17 in LT $\beta R^{\mathrm{TEC}}$ mice [33]. Importantly, and in contrast to in vivo experiments, in vitro IL-15/IL-15R $\alpha$ treatment increased numbers of iNKT1 only, suggesting that iNKT17 require additional factors that are transpresentation of IL-15 by $\mathrm{CD} 104^{+}$mTEC $^{\text {lo }}$ influences the intrathymic availability of both iNKT1 and iNKT17. In contrast, iNKT2 numbers in the thymus are regulated by IL-25, a selective product of thymic tuft cells that are generated during mTEC terminal differentiation

present within the thymus but absent in vitro [33]. Interestingly, iNKT17 show evidence of recent TCR signalling in Nur77GFP mice [100], suggesting that IL-15 transpresentation by mTEC, plus further interactions with CD1d-expressing cells in the thymus, could be required for 
iNKT17 development. Other factors have been shown to influence the development of iNKT17 including TGF $\beta$ [101], and the serine protease SerpinB1 [95]. The mechanisms behind this involvement, and any potential synergy between these pathways, are unknown.

Further evidence surrounding the importance of mTEC in iNKT cell development comes from analysis of thymic tuft cells that represent a terminally differentiated mTEC subset $[23,24]$. Interestingly, initial descriptions of iNKT cell development in tuft cell-deficient Pou $2 \mathrm{f3}^{-/-}$mice reported reductions in all 3 iNKT1, iNKT2, and iNKT17 sublineages [24]. However, a selective reduction in iNKT2 in the thymus of Pou $23^{-/}$mice was reported [33], with numbers of iNKT1 and iNKT17 remaining unaltered. That iNKT cell subset frequencies are background strain dependent may provide an explanation for this discrepancy. However, that both studies demonstrate a role for tuft cells in iNKT2 cell development is consistent with a specific reduction in iNKT2 in $I l 25^{-1}$ mice, which indicates that the importance of tuft cells in iNKT2 cell development may be explained at least in part by their selective production of IL-25 [23, 33]. This finding fits well with selective expression of IL-25 receptor by iNKT2 but not iNKT1 and iNKT17 [24]. Collectively, these observations suggest that multiple epithelial cell subsets reside within the $\mathrm{mTEC}^{\mathrm{lo}}$ population, which are functionally specialised to support the development of specific iNKT lineages.

\section{Thymus emigration and retention of iNKT cells}

While intrathymic CCR $7^{+}$iNKT cells have been shown to include cells with progenitor potential [97], these cells are also significantly enriched within the pool of iNKT RTE that are present in peripheral tissues [97]. Thus, these cells may represent the predominant iNKT cell subset that exits the thymus [97] such that $\mathrm{CCR} 7^{+}$iNKT progenitors play an important role in establishing the peripheral iNKT cell pool [97]. While expression of CCR7 and RagGFP have been investigated as potential defining markers of iNKT RTE, characterisation of RagGFP ${ }^{+}$iNKT shows an enrichment of $\mathrm{CCR} 7^{+}$cells in the lymph node but not the spleen, suggesting that while CCR7 is a RTE useful marker, it may not be a universal iNKT RTE marker [102]. In agreement with this, another study used intrathymic biotin injection to label a cohort of thymic iNKT and subsequently track these cells as RTE in the periphery. Interestingly, although $\mathrm{CCR} 7^{+}$cells were enriched within the labelled fraction, only around 50\% of iNKT RTE expressed CCR7 [97].

An additional challenge to studying iNKT RTE is that, unlike the case for conventional thymocytes, the majority of iNKT cells in the thymus are RagGFP negative. Thus, in addition to $\mathrm{RagGFP}^{+}$iNKT cells, the thymus may also control the exit of RagGFP $^{-}$iNKT cell subsets, which also either act as progenitors or represent cells that undergo lineage commitment intrathymically. In agreement with the idea that iNKT RTE undergo differentiation in the periphery, comparison of the TCR repertoire highlights significant differences between RagGFP $^{+}$iNKT RTE and RagGFP ${ }^{-}$iNKT [102]. Moreover, the TCR repertoire of iNKT cells is distinct in different peripheral tissues, showing that the clonal expansion of iNKT cells is determined by their anatomical location [102]. The frequency of RagGFP ${ }^{+}$iNKT RTE also differs between tissues, with a high proportion of RagGFP ${ }^{+}$iNKT RTE in mesenteric lymph nodes $(\mathrm{mLN})$, suggesting either a differential rate of RTE homing to certain tissues, or a more rapid turnover of RagGFP iNKT, resulting in a decline in RagGFP expression [102].

Importantly, although some iNKT RTE express CCR7 and RagGFP, whether populations of intrathymically generated iNKT1, iNKT2, and iNKT17 are permanent thymic residents or can also contribute to the peripheral pool of iNKT remains unclear $[95,97]$. Relevant to this, studies using multiple experimental approaches including thymus grafting, parabiosis, and measurement of Rag2GFP expression have shown that the majority of iNKT cells are retained within the thymus and are not under constant replenishment [97, 103]. The chemokine receptor CXCR3 has been identified as an important factor involved in the thymic retention of iNKT cells. Analysis of CXCR3-deficient mice revealed reduced frequencies of iNKT cells in the thymus and an increased frequency in the blood, suggesting its involvement in controlling the balance of iNKT cells in the thymus and peripheral circulation [104]. Furthermore, intrathymic injection of FITC into WT and $\mathrm{Cxcr}^{-/-}$mice showed increased frequencies of FITC iNKT RTE in the absence of CXCR3 [104], thus illustrating this chemokine receptor acts to prevent iNKT cell emigration from the thymus. In addition, CXCR3 is expressed most highly by iNKT1 [95], which may explain why despite their expression of S1PR1, very few iNKT1 leave the thymus.

That the thymus retains a large proportion of the iNKT cells it generates raises intriguing questions over what function these cells might possess. iNKT cells are known to be steady-state producers of cytokines, including IFN $\gamma$, IL-17, and IL-4. However, our understanding of the functional significance of these cytokines in the thymus is largely limited to IL-4. Using cell-specific deletion of CD1d, Wang et al. showed that macrophages present endogenous ligands that trigger the TCR of iNKT2 cells, resulting in IL-4 production [100]. Intrathymic production of IL-4 by iNKT cells is required for the generation of innate memory-like $\mathrm{CD}^{+}$thymocytes, which are characterised by their expression of Eomesodermin. Such $\mathrm{CD}^{+}$thymocytes are reduced to nearabsent levels in $\mathrm{Il}_{4 \mathrm{ra}^{-/}}$and $\mathrm{Cdl} \mathrm{d}^{-/}$mice [105] and are also found in much lower frequencies in $\mathrm{C} 57 \mathrm{Bl} / 6$ thymus, compared to BALB/c thymus, where IL4-producing iNKT2 are the major population of iNKT cells [94]. In addition, iNKT2 have been identified as a key regulator of thymocyte emigration, as mice deficient in either iNKT cells, or components of the IL-4 signalling pathway, show large perivascular 
accumulations of mature CD4SP thymocytes coupled with a reduction in their levels of Rag2GFP [105]. Interestingly, this study also showed that thymocyte emigration was further hindered when $\mathrm{Il}_{4 \mathrm{ra}}{ }^{-/}$mice were treated with FTY720, an agonist for S1PR1 that downregulates this receptor and so prevents S1P-mediated thymus emigration. Importantly, this finding indicates that the mechanism by which IL-4 promotes thymocyte egress is distinct from S1P [105]. As IL-4 is a signature cytokine of iNKT2, these findings suggest that iNKT2 cells represent at least some of the iNKT cells that are retained within the thymus, and suggest a functional explanation for their thymus residency. While the possible functional importance of the intrathymic retention of iNKT cells requires further study, that thymic iNKT cells regulate both DC and mTEC suggests that individual iNKT subsets play additional roles in governing multiple aspects of thymus medulla development and function $[33,34,94,97]$.

\section{Conclusions}

The importance of intrathymic microenvironments to foster and shape the $\alpha \beta$ TCR repertoire is now well established. Currently, properties of the medullary areas of the thymus are known to significantly extend beyond their capacity to induce central tolerance in conventional $\alpha \beta T$ cells. While additional support for these cells from mTEC and medulla areas includes phases of post-selection maturation and emigration into peripheral tissues, both of these aspects of medulla function remain incompletely understood. Importantly, that the role of the medulla also extends to the generation of selfregulating Foxp $3^{+} \mathrm{T}$ cells and CD1d-restricted iNKT cells, further emphasises how this site influences the diversity of intrathymic $\mathrm{T}$ cell development. By gaining a better understanding of how new heterogeneity in mTEC populations relates to the diversity of medulla functions, future research will provide insight into the development, function, and eventually the therapeutic manipulation of thymic microenvironments.

Authors' contributions All authors contributed to the writing of this manuscript.

Funding This work was funded by an MRC programme grant to GA.

\section{Compliance with ethical standards}

Conflict of interest The authors declare they have no conflicts of interest.

Open Access This article is licensed under a Creative Commons Attribution 4.0 International License, which permits use, sharing, adaptation, distribution and reproduction in any medium or format, as long as you give appropriate credit to the original author(s) and the source, provide a link to the Creative Commons licence, and indicate if changes were made. The images or other third party material in this article are included in the article's Creative Commons licence, unless indicated otherwise in a credit line to the material. If material is not included in the article's Creative Commons licence and your intended use is not permitted by statutory regulation or exceeds the permitted use, you will need to obtain permission directly from the copyright holder. To view a copy of this licence, visit http://creativecommons.org/licenses/by/4.0/.

\section{References}

1. Takahama Y, Ohigashi I, Baik S, Anderson G (2017) Generation of diversity in thymic epithelial cells. Nat Rev Immunol 17:295305

2. Kadouri N, Nevo S, Goldfarb Y, Abramson J (2020) Thymic epithelial cell heterogeneity: TEC by TEC. Nat Rev Immunol 20:239-253

3. McCaughtry TM, Hogquist KA (2008) Central tolerance: what have we learned from mice? Semin Immunopathol 30:399-409

4. Lucas B, McCarthy NI, Baik S, Cosway E, James KD, Parnell SM, White AJ, Jenkinson WE, Anderson G (2016) Control of the thymic medulla and its influence on alphabetaT-cell development. Immunol Rev 271:23-37

5. Tai X, Erman B, Alag A, Mu J, Kimura M, Katz G, Guinter T, McCaughtry T, Etzensperger R, Feigenbaum L, Singer DS, Singer A (2013) Foxp3 transcription factor is proapoptotic and lethal to developing regulatory $\mathrm{T}$ cells unless counterbalanced by cytokine survival signals. Immunity 38:1116-1128

6. Wang H, Hogquist KA (2018) How lipid-specific T cells become effectors: the differentiation of iNKT subsets. Front Immunol 9: 1450

7. Abramson J, Husebye ES (2016) Autoimmune regulator and selftolerance - molecular and clinical aspects. Immunol Rev 271:127140

8. Rodrigues PM, Peterson P, Alves NL (2018) Setting up the perimeter of tolerance: insights into mTEC physiology. Trends Immunol 39:2-5

9. Akiyama T, Shinzawa M, Akiyama N (2012) TNF receptor family signaling in the development and functions of medullary thymic epithelial cells. Front Immunol 3:278

10. Ochs HD, Gambineri E, Torgerson TR (2007) IPEX, FOXP3 and regulatory T-cells: a model for autoimmunity. Immunol Res 38: $112-121$

11. Anderson MS, Venanzi ES, Klein L, Chen Z, Berzins SP, Turley SJ, von Boehmer H, Bronson R, Dierich A, Benoist C, Mathis D (2002) Projection of an immunological self shadow within the thymus by the aire protein. Science 298:1395-1401

12. Rossi SW, Kim MY, Leibbrandt A, Parnell SM, Jenkinson WE, Glanville SH, McConnell FM, Scott HS, Penninger JM, Jenkinson EJ, Lane PJ, Anderson G (2007) RANK signals from CD4(+)3(-) inducer cells regulate development of Aire-expressing epithelial cells in the thymic medulla. J Exp Med 204:1267-1272

13. Venanzi ES, Gray DH, Benoist C, Mathis D (2007) Lymphotoxin pathway and Aire influences on thymic medullary epithelial cells are unconnected. J Immunol 179:5693-5700

14. Martins VC, Boehm T, Bleul CC (2008) Ltbetar signaling does not regulate Aire-dependent transcripts in medullary thymic epithelial cells. J Immunol 181:400-407

15. Bansal K, Yoshida H, Benoist C, Mathis D (2017) The transcriptional regulator Aire binds to and activates super-enhancers. Nat Immunol 18:263-273

16. Mathis D, Benoist C (2009) Aire. Annu Rev Immunol 27:287312

17. Org T, Rebane A, Kisand K, Laan M, Haljasorg U, Andreson R, Peterson P (2009) AIRE activated tissue specific genes have 
histone modifications associated with inactive chromatin. Hum Mol Genet 18:4699-4710

18. Chuprin A, Avin A, Goldfarb Y, Herzig Y, Levi B, Jacob A, Sela A, Katz S, Grossman M, Guyon C, Rathaus M, Cohen HY, Sagi I, Giraud M, McBurney MW, Husebye ES, Abramson J (2015) The deacetylase Sirt1 is an essential regulator of Aire-mediated induction of central immunological tolerance. Nat Immunol 16:737745

19. Takaba H, Morishita Y, Tomofuji Y, Danks L, Nitta T, Komatsu N, Kodama T, Takayanagi H (2015) Fezf2 orchestrates a thymic program of self-antigen expression for immune tolerance. Cell 163:975-987

20. Cosway EJ, Lucas B, James KD, Parnell SM, Carvalho-Gaspar M, White AJ, Tumanov AV, Jenkinson WE, Anderson G (2017) Redefining thymus medulla specialization for central tolerance. $\mathrm{J}$ Exp Med 214:3183-3195

21. Tomofuji Y, Takaba H, Suzuki HI, Benlaribi R, Martinez CDP, Abe Y, Morishita Y, Okamura T, Taguchi A, Kodama T, Takayanagi H (2020) Chd4 choreographs self-antigen expression for central immune tolerance. Nat Immunol 21:892-901

22. Gray D, Abramson J, Benoist C, Mathis D (2007) Proliferative arrest and rapid turnover of thymic epithelial cells expressing Aire. J Exp Med 204:2521-2528

23. Bornstein C, Nevo S, Giladi A, Kadouri N, Pouzolles M, Gerbe F, David E, Machado A, Chuprin A, Toth B, Goldberg O, Itzkovitz S, Taylor N, Jay P, Zimmermann VS, Abramson J, Amit I (2018) Single-cell mapping of the thymic stroma identifies IL-25producing tuft epithelial cells. Nature 559:622-626

24. Miller CN, Proekt I, von Moltke J, Wells KL, Rajpurkar AR, Wang H, Rattay K, Khan IS, Metzger TC, Pollack JL, Fries AC, Lwin WW, Wigton EJ, Parent AV, Kyewski B, Erle DJ, Hogquist KA, Steinmetz LM, Locksley RM, Anderson MS (2018) Thymic tuft cells promote an IL-4-enriched medulla and shape thymocyte development. Nature 559:627-631

25. Cowan JE, Malin J, Zhao Y, Seedhom MO, Harly C, Ohigashi I, Kelly M, Takahama Y, Yewdell JW, Cam M, Bhandoola A (2019) Myc controls a distinct transcriptional program in fetal thymic epithelial cells that determines thymus growth. Nat Commun 10:5498

26. Dhalla F, Baran-Gale J, Maio S, Chappell L, Holländer GA, Ponting CP (2020) Biologically indeterminate yet ordered promiscuous gene expression in single medullary thymic epithelial cells. EMBO J 39:e101828

27. Wang X, Laan M, Bichele R, Kisand K, Scott HS, Peterson P (2012) Post-Aire maturation of thymic medullary epithelial cells involves selective expression of keratinocyte-specific autoantigens. Front Immunol 3:19

28. Odaka C, Hauri-Hohl M, Takizawa K, Nishikawa Y, Yano M, Matsumoto M, Boyd R, Holländer GA (2013) TGF- $\beta$ type II receptor expression in thymic epithelial cells inhibits the development of Hassall's corpuscles in mice. Int Immunol 25:633-642

29. Watanabe N, Wang YH, Lee HK, Ito T, Cao W, Liu YJ (2005) Hassall's corpuscles instruct dendritic cells to induce CD4+ CD25+ regulatory T cells in human thymus. Nature 436:11811185

30. Wang J, Sekai M, Matsui T, Fujii Y, Matsumoto M, Takeuchi O, Minato N, Hamazaki Y (2018) Hassall's corpuscles with cellularsenescence features maintain IFN $\alpha$ production through neutrophils and pDC activation in the thymus. Int Immunol 31:127-139

31. White AJ, Nakamura K, Jenkinson WE, Saini M, Sinclair C, Seddon B, Narendran P, Pfeffer K, Nitta T, Takahama Y, Caamano JH, Lane PJ, Jenkinson EJ, Anderson G (2010) Lymphotoxin signals from positively selected thymocytes regulate the terminal differentiation of medullary thymic epithelial cells. J Immunol 185:4769-4776
32. Yano M, Kuroda N, Han H, Meguro-Horike M, Nishikawa Y, Kiyonari H, Maemura K, Yanagawa Y, Obata K, Takahashi S, Ikawa T, Satoh R, Kawamoto H, Mouri Y, Matsumoto M (2008) Aire controls the differentiation program of thymic epithelial cells in the medulla for the establishment of self-tolerance. J Exp Med 205:2827-2838

33. Lucas B, White AJ, Cosway EJ, Parnell SM, James KD, Jones ND, Ohigashi I, Takahama Y, Jenkinson WE, Anderson G (2020) Diversity in medullary thymic epithelial cells controls the activity and availability of iNKT cells. Nat Commun 11:2198

34. White AJ, Jenkinson WE, Cowan JE, Parnell SM, Bacon A, Jones ND, Jenkinson EJ, Anderson G (2014) An essential role for medullary thymic epithelial cells during the intrathymic development of invariant NKT cells. J Immunol 192:2659-2666

35. Mouri Y, Yano M, Shinzawa M, Shimo Y, Hirota F, Nishikawa Y, Nii T, Kiyonari H, Abe T, Uehara H, Izumi K, Tamada K, Chen L, Penninger JM, Inoue J, Akiyama T, Matsumoto M (2011) Lymphotoxin signal promotes thymic organogenesis by eliciting RANK expression in the embryonic thymic stroma. J Immunol 186:5047-5057

36. Nadjsombati MS, McGinty JW, Lyons-Cohen MR, Jaffe JB, DiPeso L, Schneider C, Miller CN, Pollack JL, Nagana Gowda GA, Fontana MF, Erle DJ, Anderson MS, Locksley RM, Raftery D, von Moltke J (2018) Detection of succinate by intestinal tuft cells triggers a type 2 innate immune circuit. Immunity 49:3341.e7

37. Owen DL, Mahmud SA, Sjaastad LE, Williams JB, Spanier JA, Simeonov DR, Ruscher R, Huang W, Proekt I, Miller CN, Hekim C, Jeschke JC, Aggarwal P, Broeckel U, LaRue RS, Henzler CM, Alegre ML, Anderson MS, August A, Marson A, Zheng Y, Williams CB, Farrar MA (2019) Thymic regulatory T cells arise via two distinct developmental programs. Nat Immunol 20:195205

38. Lkhagvasuren E, Sakata M, Ohigashi I, Takahama Y (2013) Lymphotoxin beta receptor regulates the development of CCL21-expressing subset of postnatal medullary thymic epithelial cells. J Immunol 190:5110-5117

39. Kozai M, Kubo Y, Katakai T, Kondo H, Kiyonari H, Schaeuble K, Luther SA, Ishimaru N, Ohigashi I, Takahama Y (2017) Essential role of CCL21 in establishment of central self-tolerance in T cells. J Exp Med 214:1925-1935

40. Dakic A, Shao QX, D'Amico A, O'Keeffe M, Chen WF, Shortman $\mathrm{K}, \mathrm{Wu} \mathrm{L}$ (2004) Development of the dendritic cell system during mouse ontogeny. J Immunol 172:1018-1027

41. Li J, Park J, Foss D, Goldschneider I (2009) Thymus-homing peripheral dendritic cells constitute two of the three major subsets of dendritic cells in the steady-state thymus. J Exp Med 206:607622

42. Donskoy E, Goldschneider I (2003) Two developmentally distinct populations of dendritic cells inhabit the adult mouse thymus: demonstration by differential importation of hematogenous precursors under steady state conditions. J Immunol 170:3514-3521

43. Luche H, Ardouin L, Teo P, See P, Henri S, Merad M, Ginhoux F, Malissen B (2011) The earliest intrathymic precursors of CD8alpha(+) thymic dendritic cells correspond to myeloid-type double-negative 1c cells. Eur J Immunol 41:2165-2175

44. Cosway EJ, Ohigashi I, Schauble K, Parnell SM, Jenkinson WE, Luther S, Takahama Y, Anderson G (2018) Formation of the intrathymic dendritic cell pool requires CCL21-mediated recruitment of CCR7(+) progenitors to the thymus. J Immunol 201:516523

45. Lei Y, Ripen AM, Ishimaru N, Ohigashi I, Nagasawa T, Jeker LT, Bosl MR, Hollander GA, Hayashi Y, Malefyt Rde W, Nitta T, Takahama Y (2011) Aire-dependent production of XCL1 mediates medullary accumulation of thymic dendritic cells and contributes to regulatory T cell development. J Exp Med 208:383-394 
46. Viret C, Barlow AK, Janeway CA Jr (1999) On the intrathymic intercellular transfer of self-determinants. Immunol Today 20:810

47. Kyewski B, Feuerer M (2014) Love is in the Aire: mTECs share their assets. Immunity 41:343-345

48. Gallegos AM, Bevan MJ (2004) Central tolerance to tissuespecific antigens mediated by direct and indirect antigen presentation. J Exp Med 200:1039-1049

49. Herbin O, Bonito AJ, Jeong S, Weinstein EG, Rahman AH, Xiong H, Merad M, Alexandropoulos K (2016) Medullary thymic epithelial cells and CD8alpha+ dendritic cells coordinately regulate central tolerance but CD8alpha+ cells are dispensable for thymic regulatory T cell production. J Autoimmun 75:141-149

50. Mouri Y, Nishijima H, Kawano H, Hirota F, Sakaguchi N, Morimoto J, Matsumoto M (2014) NF-kappaB-inducing kinase in thymic stroma establishes central tolerance by orchestrating cross-talk with not only thymocytes but also dendritic cells. J Immunol 193:4356-4367

51. Bonasio R, Scimone ML, Schaerli P, Grabie N, Lichtman AH, von Andrian UH (2006) Clonal deletion of thymocytes by circulating dendritic cells homing to the thymus. Nat Immunol 7:10921100

52. Hadeiba H, Lahl K, Edalati A, Oderup C, Habtezion A, Pachynski R, Nguyen L, Ghodsi A, Adler S, Butcher EC (2012) Plasmacytoid dendritic cells transport peripheral antigens to the thymus to promote central tolerance. Immunity $36: 438-450$

53. Baba T, Nakamoto Y, Mukaida N (2009) Crucial contribution of thymic Sirp alpha+ conventional dendritic cells to central tolerance against blood-borne antigens in a CCR2-dependent manner. J Immunol 183:3053-3063

54. Seth S, Oberdorfer L, Hyde R, Hoff K, Thies V, Worbs T, Schmitz S, Forster R (2011) CCR7 essentially contributes to the homing of plasmacytoid dendritic cells to lymph nodes under steady-state as well as inflammatory conditions. J Immunol 186:3364-3372

55. Atibalentja DF, Byersdorfer CA, Unanue ER (2009) Thymusblood protein interactions are highly effective in negative selection and regulatory T cell induction. J Immunol 183:7909-7918

56. Atibalentja DF, Murphy KM, Unanue ER (2011) Functional redundancy between thymic CD8alpha+ and Sirpalpha+ conventional dendritic cells in presentation of blood-derived lysozyme by MHC class II proteins. J Immunol 186:1421-1431

57. Kroger CJ, Wang B, Tisch R (2016) Temporal increase in thymocyte negative selection parallels enhanced thymic SIRPalpha+ DC function. Eur J Immunol 46:2352-2362

58. Proietto AI, van Dommelen S, Zhou P, Rizzitelli A, D'Amico A, Steptoe RJ, Naik SH, Lahoud MH, Liu Y, Zheng P, Shortman K, Wu L (2008) Dendritic cells in the thymus contribute to Tregulatory cell induction. Proc Natl Acad Sci U S A 105:1986919874

59. Ohnmacht C, Pullner A, King SB, Drexler I, Meier S, Brocker T, Voehringer D (2009) Constitutive ablation of dendritic cells breaks self-tolerance of CD4 T cells and results in spontaneous fatal autoimmunity. J Exp Med 206:549-559

60. Darrasse-Jeze G, Deroubaix S, Mouquet H, Victora GD, Eisenreich T, Yao KH, Masilamani RF, Dustin ML, Rudensky A, Liu K, Nussenzweig MC (2009) Feedback control of regulatory T cell homeostasis by dendritic cells in vivo. J Exp Med 206: 1853-1862

61. Perry JS, Lio CW, Kau AL, Nutsch K, Yang Z, Gordon JI, Murphy KM, Hsieh CS (2014) Distinct contributions of Aire and antigen-presenting-cell subsets to the generation of selftolerance in the thymus. Immunity 41:414-426

62. Weist BM, Kurd N, Boussier J, Chan SW, Robey EA. 2015. Thymic regulatory $\mathrm{T}$ cell niche size is dictated by limiting IL-2 from antigen-bearing dendritic cells and feedback competition. Nat Immunol 16:635-41.
63. Hemmers S, Schizas M, Azizi E, Dikiy S, Zhong Y, Feng Y, Altan-Bonnet G, Rudensky AY (2019) IL-2 production by selfreactive $\mathrm{CD} 4$ thymocytes scales regulatory $\mathrm{T}$ cell generation in the thymus. J Exp Med 216:2466-2478

64. Mathieson BJ, Fowlkes BJ (1984) Cell surface antigen expression on thymocytes: development and phenotypic differentiation of intrathymic subsets. Immunol Rev 82:141-173

65. Daley SR, Hu DY, Goodnow CC (2013) Helios marks strongly autoreactive CD4+ T cells in two major waves of thymic deletion distinguished by induction of PD-1 or NF-KB. J Exp Med 210: 269-285

66. Tian T, Zhang J, Gao L, Qian XP, Chen WF (2001) Heterogeneity within medullary-type TCRalphabeta(+)CD3(+)CD4(-)CD8(+) thymocytes in normal mouse thymus. Int Immunol 13:313-320

67. Boehm T, Scheu S, Pfeffer K, Bleul CC (2003) Thymic medullary epithelial cell differentiation, thymocyte emigration, and the control of autoimmunity require lympho-epithelial cross talk via LTbetaR. J Exp Med 198:757-769

68. Cowan JE, Parnell SM, Nakamura K, Caamano JH, Lane PJ, Jenkinson EJ, Jenkinson WE, Anderson G (2013) The thymic medulla is required for Foxp3+ regulatory but not conventional CD4+ thymocyte development. J Exp Med 210:675-681

69. Ge Q, Chen WF (1999) Phenotypic identification of the subgroups of murine T-cell receptor alphabeta+ CD4+ CD8- thymocytes and its implication in the late stage of thymocyte development. Immunology 97:665-671

70. Boursalian TE, Golob J, Soper DM, Cooper CJ, Fink PJ (2004) Continued maturation of thymic emigrants in the periphery. Nat Immunol 5:418-425

71. McCaughtry TM, Wilken MS, Hogquist KA (2007) Thymic emigration revisited. J Exp Med 204:2513-2520

72. Li J, Li Y, Yao JY, Jin R, Zhu MZ, Qian XP, Zhang J, Fu YX, Wu L, Zhang Y, Chen WF (2007) Developmental pathway of CD4+ CD8- medullary thymocytes during mouse ontogeny and its defect in Aire-/- mice. Proc Natl Acad Sci U S A 104:18175-18180

73. Jin R, Wang W, Yao JY, Zhou YB, Qian XP, Zhang J, Zhang Y, Chen WF (2008) Characterization of the in vivo dynamics of medullary CD4+CD8- thymocyte development. J Immunol 180: 2256-2263

74. Xing Y, Wang X, Jameson SC, Hogquist KA (2016) Late stages of $\mathrm{T}$ cell maturation in the thymus involve NF-kappaB and tonic type I interferon signaling. Nat Immunol 17:565-573

75. Burkly L, Hession C, Ogata L, Reilly C, Marconi LA, Olson D, Tizard R, Cate R, Lo D (1995) Expression of relB is required for the development of thymic medulla and dendritic cells. Nature 373:531-536

76. Weih F, Carrasco D, Durham SK, Barton DS, Rizzo CA, Ryseck RP, Lira SA, Bravo R (1995) Multiorgan inflammation and hematopoietic abnormalities in mice with a targeted disruption of RelB, a member of the NF-kappa B/Rel family. Cell 80:331-340

77. Kurobe H, Liu C, Ueno T, Saito F, Ohigashi I, Seach N, Arakaki R, Hayashi Y, Kitagawa T, Lipp M, Boyd RL, Takahama Y (2006) CCR7-dependent cortex-to-medulla migration of positively selected thymocytes is essential for establishing central tolerance. Immunity 24:165-177

78. Ueno T, Saito F, Gray DH, Kuse S, Hieshima K, Nakano H, Kakiuchi T, Lipp M, Boyd RL, Takahama Y (2004) CCR7 signals are essential for cortex-medulla migration of developing thymocytes. J Exp Med 200:493-505

79. Webb LV, Ley SC, Seddon B (2016) TNF activation of NFkappaB is essential for development of single-positive thymocytes. J Exp Med 213:1399-1407

80. Webb LV, Barbarulo A, Huysentruyt J, Vanden Berghe T, Takahashi N, Ley S, Vandenabeele P, Seddon B (2019) Survival of single positive thymocytes depends upon 
developmental control of RIPK1 kinase signaling by the IKK complex independent of NF-kB. Immunity 50:348-61.e4

81. Zachariah MA, Cyster JG (2010) Neural crest-derived pericytes promote egress of mature thymocytes at the corticomedullary junction. Science 328:1129-1135

82. Teng F, Zhou Y, Jin R, Chen Y, Pei X, Liu Y, Dong J, Wang W, Pang X, Qian X, Chen WF, Zhang Y, Ge Q (2011) The molecular signature underlying the thymic migration and maturation of TCR $\alpha \beta+C D 4+C D 8$ thymocytes. PLoS One 6:e25567

83. Hsu FC, Shapiro MJ, Chen MW, McWilliams DC, Seaburg LM, Tangen SN, Shapiro VS (2014) Immature recent thymic emigrants are eliminated by complement. J Immunol 193:6005-6015

84. Scollay R, Godfrey DI (1995) Thymic emigration: conveyor belts or lucky dips? Immunol Today 16:268-273 discussion 73-4

85. James KD, Cosway EJ, Lucas B, White AJ, Parnell SM, CarvalhoGaspar M, Tumanov AV, Anderson G, Jenkinson WE (2018) Endothelial cells act as gatekeepers for LT $\beta$ R-dependent thymocyte emigration. J Exp Med 215:2984-2993

86. Ueno T, Hara K, Willis MS, Malin MA, Hopken UE, Gray DH, Matsushima K, Lipp M, Springer TA, Boyd RL, Yoshie O, Takahama Y (2002) Role for CCR7 ligands in the emigration of newly generated $\mathrm{T}$ lymphocytes from the neonatal thymus. Immunity 16:205-218

87. Breart B, Ramos-Perez WD, Mendoza A, Salous AK, Gobert M, Huang Y, Adams RH, Lafaille JJ, Escalante-Alcalde D, Morris AJ, Schwab SR (2011) Lipid phosphate phosphatase 3 enables efficient thymic egress. J Exp Med 208:1267-1278

88. White AJ, Baik S, Parnell SM, Holland AM, Brombacher F, Jenkinson WE, Anderson G (2017) A type 2 cytokine axis for thymus emigration. J Exp Med 214:2205-2216

89. White AJ, Lucas B, Jenkinson WE, Anderson G. 2018. Invariant NKT Cells and Control of the Thymus Medulla. J Immunol 200: 3333-3339

90. Egawa T, Eberl G, Taniuchi I, Benlagha K, Geissmann F, Hennighausen L, Bendelac A, Littman DR (2005) Genetic evidence supporting selection of the Valpha14i NKT cell lineage from doublepositive thymocyte precursors. Immunity 22:705-716

91. Bendelac A, Savage PB, Teyton L (2007) The biology of NKT cells. Annu Rev Immunol 25:297-336

92. Benlagha K, Kyin T, Beavis A, Teyton L, Bendelac A (2002) A thymic precursor to the NK T cell lineage. Science 296:553-555

93. Benlagha K, Wei DG, Veiga J, Teyton L, Bendelac A (2005) Characterization of the early stages of thymic NKT cell development. J Exp Med 202:485-492

94. Lee YJ, Holzapfel KL, Zhu J, Jameson SC, Hogquist KA (2013) Steady-state production of IL-4 modulates immunity in mouse strains and is determined by lineage diversity of iNKT cells. Nat Immunol 14:1146-1154

95. Georgiev H, Ravens I, Benarafa C, Forster R, Bernhardt G (2016) Distinct gene expression patterns correlate with developmental and functional traits of iNKT subsets. Nat Commun 7:13116

96. Lee YJ, Starrett GJ, Lee ST, Yang R, Henzler CM, Jameson SC, Hogquist KA (2016) Lineage-specific effector signatures of invariant NKT cells are shared amongst gammadelta T, innate lymphoid, and Th cells. J Immunol 197:1460-1470

97. Wang H, Hogquist KA (2018) CCR7 defines a precursor for murine iNKT cells in thymus and periphery. eLife 7: e34793

98. Lee YJ, Wang H, Starrett GJ, Phuong V, Jameson SC, Hogquist KA (2015) Tissue-specific distribution of iNKT cells impacts their cytokine response. Immunity 43:566-578

99. Gordy LE, Bezbradica JS, Flyak AI, Spencer CT, Dunkle A, Sun J, Stanic AK, Boothby MR, He YW, Zhao Z, Van Kaer L, Joyce S (2011) IL-15 regulates homeostasis and terminal maturation of NKT cells. J Immunol 187:6335-6345

100. Wang H, Breed ER, Lee YJ, Qian LJ, Jameson SC, Hogquist KA (2019) Myeloid cells activate iNKT cells to produce IL-4 in the thymic medulla. Proc Natl Acad Sci U S A 116:22262-22268

101. Havenar-Daughton C, Li S, Benlagha K, Marie JC (2012) Development and function of murine RORgammat+ iNKT cells are under TGF-beta signaling control. Blood 119:3486-3494

102. Jimeno R, Lebrusant-Fernandez M, Margreitter C, Lucas B, Veerapen N, Kelly G, Besra GS, Fraternali F, Spencer J, Anderson G, Barral P (2019) Tissue-specific shaping of the TCR repertoire and antigen specificity of iNKT cells. eLife 8: e51663

103. Berzins SP, McNab FW, Jones CM, Smyth MJ, Godfrey DI (2006) Long-term retention of mature NK1.1+ NKT cells in the thymus. J Immunol 176:4059-4065

104. Drennan MB, Franki AS, Dewint P, Van Beneden K, Seeuws S, van de Pavert SA, Reilly EC, Verbruggen G, Lane TE, Mebius RE, Deforce D, Elewaut D (2009) Cutting edge: the chemokine receptor CXCR3 retains invariant NK T cells in the thymus. $\mathrm{J}$ Immunol 183:2213-2216

105. Weinreich MA, Odumade OA, Jameson SC, Hogquist KA (2010) $\mathrm{T}$ cells expressing the transcription factor PLZF regulate the development of memory-like CD8+ T cells. Nat Immunol 11:709716

Publisher's note Springer Nature remains neutral with regard to jurisdictional claims in published maps and institutional affiliations. 